\title{
Pelatihan Keterampilan Esensial Konseling untuk Konselor Sekolah dengan Structured Learning Approach
}

\author{
Diniy Hidayatur Rahman ${ }^{1}$, Widya Multisari², Devy Probowati ${ }^{3}$ \\ ${ }^{1,2,3}$ Fakultas Ilmu Pendidikan, Universitas Negeri Malang \\ Email: diniy.hidayatur.fip@um.ac.id ${ }^{1}$
}

\begin{abstract}
ABSTRAK
Salah satu permasalahan pelik yang dialami oleh para konselor sekolah di lingkungan Kementerian Agama Kabupaten Probolinggo adalah rendahnya keterampilan konseling. Hal ini karena sebagian besar mereka tidak berlatarbelakang pendidikan sarjana bimbingan dan konseling. Selama ini, proses konseling dilakukan dengan cara yang lebih mirip dengan pemberian nasehat daripada konseling profesional. Berdasarkan kondisi tersebut, dilakukan pelatihan untuk meningkatkan keterampilan esensial konseling untuk para konselor dimaksud. Melalui pelatihan ini, diharapkan agar para konselor dapat meningkatkan: (1) keterampilan mendengarkan secara aktif; (2) keterampilan mempengaruhi; dan (3) keterampilan pemberian bantuan pemecahan masalah melalui prosedur-prosedur konseling secara umum. Kegiatan inidilaksanakan dengan menggunakan pendekatan structured learning approach (SLA) dengan sistem In, On, dan In. Secara keseluruhan, kegiatan pelatihan dilaksanakan selama tiga bulan. Hasil kegiatan menunjukkan bahwa terdapat peningkatanpengetahuan dan keterampilan konseling para peserta. Hal ini dibuktikan dengan peningkatan skor-skor pengetahuan dan keterampilan mereka ke arah yang lebih baik.
\end{abstract}

Kata Kunci: keterampilan esensial konseling; bimbingan dan konseling; structured learning approach

\section{Counseling Essential Skills Training for School Counselors with a Structured Learning Approach}

\begin{abstract}
One of the most compliacated problems of school counselors in Kementerian Agama Kabupaten Probolinggo is the lack of their counseling skills. This is because their educational background is not related to guidance and counseling. Prior to this program, their counseling service was carried out in a way that could be called advice giving rather than professional counseling. Based on the situation, the program aims to improve the essential counseling skills of the counselors. The program is expected to improve the counselors': (1) active listening skills; (2) influencing skills; and (3) skills in providing problem solving. The program is implemented with a structured learning approach (SLA) and In-On-In procedure. Overall, the entire program was carried out in three months. The result of the program is the improvement of the counselors' understanding and skills in giving counseling service.
\end{abstract}

Keywords: essential counseling skills; guidance and counseling; structured learning approach

PENDAHULUAN

Forum Musyawarah Guru Bimbingan dan Konseling (MGBK) Kementerian Agama Kabupaten
Probolinggo merupakan wadah musyawarah dan peningkatan profesionalisme guru-guru bimbingan dan konseling di kabupaten tersebut. 
Sekretariat forum tersebut terletak di MTs. Negeri 1 Probolinggo, Dusun Krajan, Karanganyar, Paiton, Probolinggo. Forum ini membawahi 25 Madrasah Tsanawiyah dan Aliyah, di mana dua di antaranya adalah Madrasah Tsanawiyah dan Aliyah Negeri. Berdasarkan informasi yang diperoleh dari studi pendahuluan, MGBK ini melakukan pertemuan rutin sekali dalam satu bulan. Pertemuan biasanya berisi kegiatan pelatihan yang bersifat kolegial dan diselenggarakan secara swadaya. Pada saat-saat tertentu, forum ini juga mengundang narasumber ahli dari perguruan tinggi maupun praktisi bimbingan dan konseling dari lembaga lain.

Sebagaimana di wilayah tapal kuda lainnya yang berbudaya Madura, sekolah-sekolah di Kabupaten Probolinggo didominasi oleh sekolah swasta yang berafiliasi pada yayasan pondok pesantren. Hal ini berdampak pada kualifikasi konselor sekolah yang dimiliki oleh sekolah-sekolah tersebut. Sebagian besar konselor berlatar belakang sarjana selain Bimbingan dan Konseling sehingga berdampak pada rendahnya keterampilan pemberian layanan bimbingan dan konseling. Namun demikian, motif altruistik yang tinggi pada para konselor tersebut membuat mereka bersemangat untuk mempelajari keterampilan-keterampilan esensial yang diperlukan dalam memberikan layanan bimbingan dan konseling.

Hasil penelitian Janu (2011) menunjukkan bahwa keterampilan konseling para konselor berada dalam kategori rendah. Kondisi ini juga terjadi pada para konselor di Kabupaten Probolinggo. Berdasarkan hasil wawancara dengan Ketua MGBK, terdapat beberapa masalah yang dihadapi oleh para konselor di wilayah ini. Masalah-masalah tersebut antar lain: (1) pemahaman hakikat dan fungsi BK di sekolah; (2) keterampilan penyusunan program BK; (3) keterampilan konseling; dan (4) keterampilan penyelenggaraan layanan bimbingan kelompok. Di antara masalah-masalah tersebut, beberapa konselor berpendapat bahwa rendahnya keterampilan konseling merupakan masalah yang paling urgen untuk segera diselesaikan. Hal ini karena keterampilan tersebut diperlukan untuk membantu siswasiswa yang memiliki masalah tertentu. Sementara ini, proses konseling dilakukan dengan cara yang lebih mirip dengan pemberian nasehat daripada konseling profesional. Berdasarkan kondisi tersebut, dilaksanakanlah pelatihan untuk meningkatkan keterampilan esensial konseling para konselor dimaksud.

Ivey, Ivey, \& Zalaquett (2010: 363) menjelaskan bahwa terdapat beberapa keterampilan esensial konseling yang perlu dikuasai oleh konselor. Keterampilan tersebut terklasifikasi menjadi keterampilan mendengarkan secara aktif, keterampilan mempengaruhi, dan pendekatan penyelesaian masalah. Integrasi ketiga keterampilan tersebut yang dilandasi oleh motif altruistik, etika, dan kompetensi multikultural, akan mengerucut menjadi tampilan 
praktik konseling profesional yang 'menyembuhkan'.

Lebih lanjut, Lambert (1992) mengidentifikasi faktor-faktor yang berkontribusi pada keberhasilan konseling, yaitu: faktor perubahan ekstraterapeutik, faktor hubungan terapeutik, faktor ekspektansi, dan faktor teknik-teknik spesifik. Di antara keempat faktor tersebut, faktor perubahan ekstraterapeutik menyumbang $40 \%$ pada keberhasilan konseling, faktor hubungan terapeutik sebesar 30\%, faktor ekspektansi sebesar $15 \%$, dan faktor teknik-teknik spesifik sebesar $15 \%$. Faktor hubungan terapeutik dan faktor teknik-teknik spesifik merupakan faktor yang dapat diusahakan oleh konselor, sementara sisanya merupakan faktor di luar kuasa konselor. Berdasarkan kajian oleh Ivey, dkk. (2010) dan temuan Lambert (1992) di atas, kemampuan untuk menjalin hubungan terapeutik hendaknya lebih diutamakan untuk dikuasai oleh konselor. Karena itu, pelatihan ini bertujuan untuk melatihkan keterampilanketerampilan menjalin hubungan terapeutik, yang dalam hal ini disebut sebagai keterampilan esensial dalam konseling.

Secara umum, terdapat dua klasifikasi keterampilan esensial dalam konseling, yaitu keterampilan mendengarkan secara aktif (active listening) dan keterampilan mempengaruhi (influencing) (Ivey, dkk., 2010). Secara spesifik, keterampilan mendengarkan secara aktif terdiri dari keterampilan bertanya (questioning), mengulang kata atau kalimat (restatement), menerima (acceptance), memparafrasa (paraphrasing), merefleksi perasaan (reflection of feeling), berdiam (silence), dan sejenisnya. Adapun keterampilan mempengaruhi terdiri dari keterampilan mengkonfrontasi (confrontation), menunjukkan sudut pandang baru (reframing), menjamin (reassurance), membuka diri (selfdisclosure), dan menasehati (advice) (Mulawarman, 2017). Penggunaan keterampilan-keterampilam tersebut secara tepat dengan dilandasi oleh motif altruistik yang kuat akan membangkitkan faktor hubungan terapeutik yang memiliki kontribusi sebesar 30\% bagi keberhasilan konseling (Lambert, 1992).

Terdapat berbagai metode dan pendekatan pembelajaran yang dapat digunakan untuk melatihkan keterampilan esensial dalam konseling. Di antara keterampilanketerampilantersebutmisalnyaadalah: structured learning approach (SLA) (Handarini, 2000; Damayanti, 2015; Rudati, 2018), experiential learning (Sholihah, Utaya, Sholihah, 2016; Saud, Saleh, \& Asnur, 2018), dan sosiodrama (Siregar, 2014). Di antara pendekatan-pendekatan pembelajaran tersebut, SLA merupakan pendekatan yang paling integratif. Hal ini karena SLA mengintegrasikan belajar eksperiensial dan bermain peran sekaligus secara terstruktur dalam format pembelajaran. Demikian pula, SLA sangat tepat digunakan dalam konteks pembelajaran orang dewasa yang penuh dengan pemaknaan dan abstraksi. Karena itu, kegiatan 
pelatihaninimenggunakanpendekatan SLA untuk melatihkan keterampilan esensial dalam konseling.

\section{METODE PENELITIAN}

Untuk mencapai target dan luaran yang disebutkan di atas, dilaksanakan pelatihandengan topik "Pelatihan Keterampilan Esensial dalam Konseling". Dalam pelatihantersebut, para peserta difasilitasi untuk memahamidanterampilmenggunakan: (1) keterampilan mendengarkan secara aktif; (2) keterampilan mempengaruhi; dan (3) keterampilan memberikan bantuan pemecahan masalah dalam konseling.

Untuk memfasilitasi para peserta agar menjadi aktif dalam mengkonstruksi pemahaman dan keterampilannya sendiri, pelatihan menggunakan pendekatan structured learning approach (SLA). SLA merupakan sebuah pendekatan pembelajaran di mana fasilitator menstruktur para peserta agar mempelajari hal-hal tertentu dalam seting yang sudah ditentukan. Tugas fasilitator dalam hal ini adalah menstruktur hal-hal yang akan dipelajari oleh para peserta secara sistematis. Pendekatan ini mengikuti tahap-tahap sebagai berikut: (1) instructing, yaitu fasilitator memberikan instruksi tentang apa saja yang harus dipelajari secara mandiri oleh para peserta workshop; (2) modelling, yaitu fasilitator memberikan contoh bagaimana cara memperoleh informasi/keterampilan yang diinstruksikan di tahap 1; (3) role playing, yaitu para peserta workshop mulai berlatih keterampilan yang diinstrusikan; dan (4) feedback, yaitu fasilitator memberikan balikan atas ketepatan atau ketidaktepatan keterampilan yang diperoleh para peserta. Tahap dan siklus tersebut dapat dilakukan secara berulang hingga target yang diinginkan tercapat. Agar dapat terlaksana dengan baik, pendekatan SLA tersebut didukung dengan sarana berupa handout materi, kertas plano, spidol, perekat, dan LCD projector.

Dalam pelatihanini, 50 konselor sekolah di lingkungan Kementerian Agama Kabupaten Probolinggo berpartisipasi aktif sebagai peserta. Mereka difasilitasi untuk memperoleh keterampilan seperti yang telah disebutkan di atas. Sesuai dengan pendekatan pelatihan yang digunakan, para peserta berlatih keterampilan mendengarkan, mempengaruhi, dan membantu memecahkan masalah secara terstruktur dan mandiri dalam seting kelas dan dalam seting nyata. Karena itu, pelatihan ini dilakukan dengan sistem In 1, On, dan In 2. Secara umum, rincian kegiatan pelatihan tampak pada tabel 1. Dalam hal ini, pelatihan secara keseluruhan dilaksanakan dalam waktu tiga bulan, di mana porsi terbesar adalah pada praktikum mandiri (On).

Tabel 1: Rincian Kegiatan Pelatihan

\begin{tabular}{|l|l|l|}
\hline Tahap & \multicolumn{1}{|c|}{ Kegiatan } & Waktu \\
\hline In 1 & - $\begin{array}{l}\text { Belajar terstruktur dengan } \\
\text { topik: (1) Konseling: Mengerti } \\
\end{array}$ & 2 hari \\
& yang Menyembuhkan; (2) & \\
& Prosedur Umum Konseling; & \\
& (3) Keterampilan Esensial 1: & \\
& Mendengarkan Secara Aktif; & \\
& (4) Keterampilan Esensial 2: & \\
& Mempengaruhi; (5) Pemberian & \\
\hline
\end{tabular}




\begin{tabular}{|c|c|c|}
\hline Tahap & Kegiatan & Waktu \\
\hline & $\begin{array}{l}\text { Bantuan Pemecahan Masalah } \\
\text { dalam Konseling. } \\
\text { - Praktikum konseling } \\
\text { tersupervisi }\end{array}$ & \\
\hline On & $\begin{array}{l}\text { Implementasi keterampilan } \\
\text { esensial dalam pelayanan } \\
\text { konseling } \\
\text { - Konseli } 1 \text { (minimal } 3 \text { sesi } \\
\text { konseling) } \\
\text { - Konseli } 2 \text { (minimal } 3 \text { sesi } \\
\text { konseling) } \\
\text { - Konseli } 3 \text { (minimal } 3 \text { sesi } \\
\text { konseling) }\end{array}$ & 3 bulan \\
\hline In 2 & $\begin{array}{l}\text { - Presentasi laporan pelaksanaan } \\
\text { konseling } \\
\text { - Feedback dan perbaikan praktik } \\
\text { konseling } \\
\text { - Refleksi dan evaluasi } \\
\text { pelaksanaan praktikum } \\
\text { konseling }\end{array}$ & 1 hari \\
\hline
\end{tabular}

Untuk memastikan bahwa pelatihan ini menghasilkan luaranluaran pengetahuan dan keterampilan seperti yang telah ditentukan di atas, digunakan instrumen evaluasi berupa tes keterampilan esensial konseling dan pedoman observasi keterampilan esensial konseling. Sebelum digunakan, kedua instrumen tersebut diuji oleh tiga ahli bimbingan dan konseling untuk memastikan validitas isinya. Hasil pengujian menunjukkan bahwa kedua instrumen valid dan layak digunakan. Tes keterampilan esensial konseling kemudian diberikan kepada peserta sebelum kegiatan In 1, setelah kegiatan On, dan setelah kegiatan In 2. Adapun observasi dilakukan kepada lima peserta saat praktikum In 1 dan perbaikan praktikum In 2 .

\section{HASIL DAN PEMBAHASAN}

Melalui langkah-langkah SLA seperti disebutkan di atas, diperoleh dua hasil pelaksanaan, yaitu hasil kognitif dan keterampilan. Dalam hal ini, hasil kognitif berbentuk peningkatan pemahaman peserta tentang keterampilan esensial dalam konseling, yang meliputi keterampilan mendengarkan secara aktif, keterampilan mempengaruhi, dan prosedur umum konseling. Hasil ini dievaluasi dengan menggunakan tes keterampilan esensial dalam konseling yang diadministrasikan sebelum dan setelah kegiatan In 1, serta setelah In 2. Adapun hasil keterampilan berbentuk peningkatan performansi keterampilan esensial dalam konseling. Hasil ini dievaluasi dengan observasi performansi keterampilan esensial dalam konseling yang dilakukan sebelum In 1 dan setelah On 1. Pada tabel 2 disajikan rata-rata hasil tes keterampilan esensial dalam konseling sebelum dan setelah In 1, serta setelah In 2.

Berdasarkan tabel 2, dapat diketahui bahwa pengetahuan awal peserta pelatihan tentang keterampilan esensial konseling sangat rendah. Hasil ini berkorelasi dengan penelitian Janu (2011) yang menyatakan bahwa para konselor memiliki kompetensi yang rendah dalam keterampilan konseling. Melakukan konseling memang merupakan kegiatan yang kompleks. Ia tidak hanya menyangkut kepiawaian dalam mendiagnosa masalah dan memperkirakan treatmentnya, namun juga tentang bagaimana berinteraksi secara terapeutik dengan subjek yang berpikir dan merasa.

Tabel 2: Perubahan Pengetahuan Peserta Pelatihan Sebelum dan Pasca Pelatihan

\begin{tabular}{|c|c|c|c|c|c|}
\hline $\begin{array}{c}\text { Rata2 } \\
\text { In 1 }\end{array}$ & $\begin{array}{c}\text { Klasi- } \\
\text { fikasi }\end{array}$ & $\begin{array}{c}\text { Rata2 } \\
\text { On }\end{array}$ & $\begin{array}{c}\text { Klasi- } \\
\text { fikasi }\end{array}$ & $\begin{array}{c}\text { Rata2 } \\
\text { In 2 }\end{array}$ & $\begin{array}{c}\text { Klasi- } \\
\text { fikasi }\end{array}$ \\
\hline 5,98 & Rendah & 13,73 & Sedang & 15,44 & Sedang \\
\hline
\end{tabular}


Demikian pula, pada tabel 3 disajikan hasil observasi performansi keterampilan esensial lima peserta pelatihan. Observasi hanya dilakukan pada lima peserta terpilih karena keterbatasan waktu dan tenaga observer. Observasi dilakukan saat praktikum konseling tersupervisi pada tahap In 1 dan saat perbaikan praktikum konseling pada tahap In 2 .

Tabel 3: Perubahan Keterampilan Esensial Peserta Pelatihan Sebelum dan Pasca Pelatihan

\begin{tabular}{|c|c|c|c|c|c|c|c|c|c|c|c|}
\hline \multirow{2}{*}{ No. } & \multirow{2}{*}{ Nama } & \multicolumn{2}{|c|}{1} & \multicolumn{2}{|c|}{2} & \multicolumn{2}{|c|}{3} & \multicolumn{2}{|c|}{4} & \multicolumn{2}{|c|}{5} \\
\hline & & Pra & $\mathrm{Psc}$ & Pra & Psc & Pra & Psc & Pra & $\mathrm{Psc}$ & Pra & Psc \\
\hline 1. & $\mathrm{R}$ & 2 & 6 & 2 & 4 & 2 & 5 & 2 & 4 & 2 & 6 \\
\hline 2. & US & 2 & 5 & 2 & 4 & 2 & 5 & 2 & 5 & 3 & 6 \\
\hline 3. & SM & 2 & 6 & 2 & 4 & 2 & 6 & 2 & 5 & 3 & 6 \\
\hline 4. & I & 2 & 5 & 2 & 4 & 2 & 5 & 2 & 5 & 3 & 6 \\
\hline 5. & AS & 5 & 7 & 4 & 6 & 5 & 7 & 5 & 7 & 6 & 8 \\
\hline \multicolumn{12}{|c|}{$\begin{array}{l}\text { Keterangan: } \\
\text { 1=mengawali pertemuan; } 2=\text { pengumpulan data; } 3=\text { perumusan } \\
\text { tujuan; } 4=\text { =working; } 5=\text { pengakhiran }\end{array}$} \\
\hline $\begin{array}{l}\text { Pedor } \\
89\end{array}$ & 0 (tingg & ing: 1 & & & adah) & & 56 & 7 (s & edang & & \\
\hline
\end{tabular}

Berdasarkan skor-skor pada tabel tersebut, dapat disimpulkan bahwa pelatihan keterampilan esensial dalam konseling ini dapat meningkatkan pengetahuan dan keterampilan para peserta dalam melakukan konseling. Hasil tersebut tidak mengherankan mengingat beberapa penelitian sebelumnya telah membuktikan bahwa SLA efektif untuk meningkatkan pemahaman dan melatihkan keterampilan (Handarini, 2000; Damayanti, 2015; Rudati, 2018). Dalam pelatihan dengan SLA, fasilitator memberikan instruksi dan memberikan contoh secara spesifik tentang apa yang harus dilakukan oleh peserta pelatihan. Selanjutnya, peserta pelatihan berlatih sesuai instruksi dan diberi balikan oleh rekan dan fasilitatornya. Siklus tersebut dilakukan secara berulang sehingga pengetahuan dan keterampilan yang ditargetkan dapatdicapai. Dalamsiklus tersebut, terjadi proses pembiasaan dan perbaikan perilaku. Dengan demikian, seiring dengan berulangnya siklus, perilaku/ keterampilan yang dilatihkan akan semakin membaik.

Hanya saja, berdasarkan skor di tabel 2 dan 3 tersebut, sebagian besar pengetahuan dan keterampilan para peserta masih berada pada klasifikasi menengah bawah. Hal ini menjadi wajar mengingat waktu tatap muka pelatihan yang relatif singkat. Meskipun peserta memiliki kesempatan yang cukup luas untuk berlatih di lapangan, namun feedback yang diberikan oleh rekan dan fasilitator hanya terjadi dalam ruangan pelatihan sesuai jadwal. Karena itu, untuk lebih menyempurnakan hasil yang telah diperoleh, masih diperlukan pelatihan lainnya sebagai tindak lanjut dari pelatihan ini.

\section{SIMPULAN}

Berdasarkan hasil dan pembahasan yang telah disebutkan, dapat diambil beberapa kesimpulan sebagai berikut: (1) kegiatan pelatihan ini telah mencapai targettarget yang direncanakan, yaitu untuk meningkatkan pengetahuan dan keterampilan konseling para peserta. Meski demikian, peningkatan tersebut masih terbatas pada klasifikasi Sedang Bawah; (2) sejalan dengan kesimpulan pada poin 1, penggunaan pendekatan SLA untuk melatih keterampilan esensial konseling sangat tepat. Hal ini ditunjukkan oleh peningkatan 
skor yang baik pada sebagian besar peserta; (3) pelatihan keterampilan konseling memerlukan waktu dan dana yang cukup untuk menghasilkan peningkatan pengetahuan dan keterampilan hingga klasifikasi Tinggi.

\section{SARAN}

Sesuai dengan deskripsi kesimpulan di atas, diajukan saran agar Forum Musyawarah Guru BK Madrasah Kabupaten Probolinggo menyelenggarakan pelatihanpelatihan lanjutan dengan pendekatan SLA dan atau pembelajaran eksperiensial. Pelatihan-pelatihan yang direkomendasikan yaitu: (1) pelatihan keterampilan esensial konseling tingkat lanjut, yang berisi pendalaman keterampilanketerampilan komunikasi dalam konseling; (2) pelatihan pemberian bantuan pemecahan masalah dengan model konseling tertentu, seperti solution-focused brief counseling dan konseling realitas; dan (3) pelatihan teknik-teknik intervensi dalam konseling, seperti: metafora, kursi kosong, dan relaksasi.

\section{DAFTAR PUSTAKA}

Damayanti, N. 2015. Pengembangan PanduanPelatihanKeterampilan Menyusun Perencanaan Hidup dengan Strategi Structured Learning Approach (SLA) untuk Siswa Sekolah Menengah Pertama (SMP). Skripsi, tidak diterbitkan. Malang: Jurusan Bimbingan dan Konseling Universitas Negeri Malang

Handarini, D. 2000. Pengembangan model pelatihan keterampilan sosial bagi siswa Sekolah
Menengah Umum Terpadu. Disertasi, tidak diterbitkan. Malang: Jurusan Bimbingan dan Konseling Universitas Negeri Malang

Ivey, A.E., Ivey, M.B., \& Zalaquett, C.P. 2010. Intentional Interviewing \& Counseling. Belmont, CA: Brooks/Cole, Cengage Learning.

Janu, A. 2011. Riset Evaluatif Penyelenggaraan Layanan Konseling di SMA Se-Kota Malang. Tesis, tidak diterbitkan. Malang: Pascasarjana Universitas Negeri Malang.

Lambert, M. J. 1992. Implications of outcome research for psychotherapy integration. Dalam J. C. Norcross \& M. R. Goldstein (Eds.), Handbook of Psychotherapy Integration (hlm. 94-129). New York: Basic Books.

Mulawarman. 2017. Buku Ajar Pengantar Keterampilan Dasar Konseling bagi Konselor Pendidikan. Semarang: Jurusan Bimbingan dan Konseling Universitas Negeri Semarang.

Rudati, I. 2018. Pengembangan panduan pelatihan keterampilan menyelesaikan konflik secara konstruktif untuk mencegah bullying bagi siswa SMP dengan menggunakan model Structured Learning Approach (SLA). Skripsi, tidak diterbitkan. Malang: Jurusan Bimbingan dan Konseling Universitas Negeri Malang.

Saud, S., Saleh, N., Asnur, M. N. A. 2018. Dampak Experiential Learning dalam Pembelajaran Keterampilan Berbicara Bahasa Jerman Mahasiswa di Perguruan Tinggi. Artikel ini Dipresentasikan pada Seminar Nasional Dies Natalis UNM Ke 57, di Makassar, tanggal 9 Juli 2018. 
Siregar, M. M. 2014. Penerapan Metode Sosiodrama untuk Meningkatkan Kemampuan Interpersonal Siswa Kelas VII SMP Negeri 5 Depok Sleman Yogyakarta. Skripsi, tidak diterbitkan. Yogyakarta: Jurusan Psikologi Pendidikan dan Bimbingan Universitas Negeri Yogyakarta.

Sholihah, M., Utaya, S., Susilo, S. 2016. Pengaruh Model Experiential Learning terhadap Kemampuan Berpikir Siswa SMA. Jurnal Pendidikan: Teori, Penelitian dan Pengembangan, 1(11): 2096-2100. 